\title{
Early selection of elite clones of an ornamental bromeliad in vitro
}

\author{
Seleção precoce in vitro de clones elite de uma bromélia ornamental
}

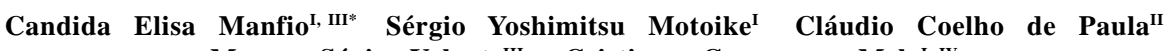

Magno Sávio Valente ${ }^{I I I}$ Cristiane Gamarano Melo', IV

\begin{abstract}
Orthophytum grossiorum is a typical bromeliad from Atlantic forestry threatened of extinction. The objectives of this research were to select $\boldsymbol{O}$. grossiorum clones with ornamental values easy to propagate in vitro, and establish in vitro propagation protocols for these clones. The project was developed in three steps: germination and in vitro selection of seedlings responsive to BAP (6benzylaminopurine), selection of clones with ornamental values, and establishment of protocol for in vitro propagation of the selected clones. In the first step only $18.33 \%$ of plantlets germinated in vitro were responsive to BAP. These plantlets were selected and replicated in vitro several times, each replicated plantlet constituting a clone. In the second step these clones were established ex vitro and surveyed for ornamental attributes. Five out of 11 clones were selected in this step. These clones presented distinct phenotypic traits and were considered of high ornamental quality. In the third step a protocol for in vitro propagation was developed for each selected clone.
\end{abstract}

Key words: micro-propagation, tissue culture, breeding.

\section{RESUMO}

Orthophytum grossiorum é uma bromélia ameaçada de extinção típica de Mata Atlântica. Os objetivos deste trabalho foram selecionar clones de $\boldsymbol{O}$. grossiorum com potencial ornamental e de fácil propagação in vitro $e$ estabelecer protocolo de propagação in vitro para esses clones. $O$ trabalho foi desenvolvido em três etapas: germinação e em seleção in vitro de plântulas responsivas a BAP (6- benzylaminopurine), seleção de clones com valores ornamentais e estabelecimento de protocolo para propagação in vitro dos clones selecionados. Na primeira etapa, foi observado que apenas $18.33 \%$ das plântulas germinadas in vitro eram responsivas a BAP. Essas plântulas foram selecionadas e reproduzidas em in vitro, e cada plântula selecionada e reproduzida constituiu um clone. Na segunda etapa, esses clones foram estabelecidos ex vitro e selecionados em relação aos atributos ornamentais. Nessa etapa, foram selecionados cinco entre 11 clones. Esses apresentaram características fenotípicas distintas, sendo considerados de alta qualidade ornamental. Na terceira etapa, o protocolo para em propagação in vitro foi desenvolvido para cada clone selecionado.

Palavras-chave: micropropragação, cultura de tecido, melhoramento.

\section{INTRODUCTION}

Considering the current growing concern with the environment, and Brazil being one of the largest centers of biological diversity in the world, emphasis has been given to stimulating the search for alternatives for preservation and conservation of certain species. One of the alternatives is to provide plants grown in nurseries to the market, to reduce the pressure of exploitation of the wild ornamental specimens.

\footnotetext{
'Departamento de Fitotecnia, Universidade Federal de Viçosa (UFV), 36570-000, Viçosa, MG, Brasil. E-mail: cemanfio@yahoo.com.br *Autor para correspondência.

IIDepartamento de Botânica, UFV, Viçosa, MG, Brasil.

IIIPrograma de Pós-graduação em Genética e Melhoramento, UFV, Viçosa, MG, Brasil.

IVPrograma de Pós-graduação em Fitotecnia, UFV, Viçosa, MG, Brasil.
} 
Orthophytum grossiorum is a new species of Bromeliaceae from Brazil described and illustrated by LEME \& PAULA (2003). O. grossiorum is a bromeliad at risk of extinction (MMA, 2009) and present several ornamental characteristics. The species present distinct basal rhizomes, lepidote leaves, smaller spines on leaf margin, inflorescence sometimes compound, yellow floral bracts with smaller marginal spines, and smaller flowers. It also displays intense contrasting colors with brownish red leaves and its yellow floral bracts (LEME \& PAULA, 2003). These characteristics combined with rusticity, small size, easy handling and adaptation as well as long-lasting inflorescence, makes it a perfect ornamental plant to be commercially explored (ANDERSON, 2007). However, it is not cultivated commercially, since no agronomically-defined techniques are currently available at a commercial scale. To transform this species into a commercial ornamental plant $\boldsymbol{O}$. grossiorum has to be tailored in two aspects: easy propagation and uniform clones.

The first step in the breeding of a wild plant species is to define its propagation methods. The propagation of bromeliads can occur both through the seminiferous via and by natural vegetative propagation using axillary shoots (BENZING, 2000). The vegetative process is the most used method of propagation for commercial purposes.

Vegetative propagation in vitro, also known as micro-propagation, is a practical form of tissue culture that has great impact on the propagation of new clones. This system allows rapid clone multiplication with high genetic fidelity. In cultivation in vitro, the addition of growth regulators to the cultivation medium, (specifically, cytokinins) is indispensable for breaking apical dominance and axillary bud induction (PAEK \& HAHN, 2000). Of the cytokinins commercially available, 6benzylaminopurine (BAP) is the most commonly used, because it is cheap and highly efficient in promoting multiplication in several bromeliad species (GUERRA et al., 1999; MERCIER \& NIEVOLA, 2003; PASQUAL et al., 2008).

For a successful in vitro vegetative propagation, it is fundamental that the selected clones react to the stimuli applied to the growth environment, especially to growth regulators. However, the response of different plant species that are cultured in vitro, varies as a function of the genotype and the cultivation conditions (MERCIE \& NIEVOLA, 2003). One genotype-dependent particularity is that many genotypes are recalcitrant to cultivation in vitro.
For some bromeliads the in vitro cultivation can be a easy and simple method that provides a high rate of multiplication and production of healthy plants, and representes a wide variety of genotypes in space and a shorter time (RECH FILHO et al., 2005; POMPELLI \& GUERRA, 2006; SILVA et al., 2007).

Therefore, this research aimed to test a precocious selection of genotypes in vitro of $\boldsymbol{O}$. grossiorum to obtain clones that are easy to propagate in vitro and with ornamental potential.

\section{MATERIAL AND METHODS}

This research was taken at the Laboratory of Cell and Plant Tissue Culture and at the Bromaliaceae Conservation and Research Unit (UPCB). The research was carried out in three stages: germination and selection of plantlets responsive to BAP (6-benzylaminopurine), selection of high ornamental quality clones and protocol adjustment for the in vitro propagation of each of the selected clones.

For the germination and selection of BAP responsive plantlets, one ripe fruit (berries) of $\boldsymbol{O}$. grossiorum, obtained by open pollination, were collected from one matrix plants established at the Bromeliaceae Conservation and Research Unit(UPCB), in Viçosa-MG, and cleaned by washing in running water for 30 minutes. The sixty-three seeds extracted from these fruit were then disinfected as follows: immersion in alcohol $70 \%(\mathrm{v} / \mathrm{v})$ for one minute, rinsing in sterile deionized water, followed by immersion in sodium hypochlorite ( $2.0 \%$ of active chlorine) and Tween 20 $(0,01 \%)$ for 15 minutes. Throughout the disinfection process, the seeds were under agitation; afterwards, they were rinsed three times in sterile deionized water, followed by inoculation in culture medium containing $50 \%$ MS (MURASHIGE \& SKOOG, 1962) (macro and micro salts) and supplemented with $30 \mathrm{~g} \mathrm{l}^{-1} \mathrm{MS}$ sucrose, vitamins and $100 \mathrm{mg} \mathrm{l}^{-1}$ myo-inositol. Medium $\mathrm{pH}$ was adjusted to $5.7 \pm 0.01$ and the medium was solidified with $8.0 \mathrm{~g} \mathrm{l}^{-1}$ agar (Grupo Química ${ }^{\circledR}$ ); $10 \mathrm{~mL}$ of the medium was placed in assay tubes measuring $25 \times 150 \mathrm{~mm}$, and autoclaved at $121^{\circ} \mathrm{C}$ and $1.5 \mathrm{~atm}$ for 20 minutes. The tubes were sealed with plastic lids and transparent PVC film. After inoculation, the explants were transferred to the growth chamber at $25 \pm 2^{\circ} \mathrm{C}$, with a photoperiod of 16 hours and irradiance of $40 \mu \mathrm{mol} \mathrm{m} \mathrm{m}^{-2} \mathrm{~s}^{-1}$, supplied by $40 \mathrm{~W}$ white fluorescent bulbs (Philips ${ }^{\circledR}$ ).

Based in our preliminary studies, performed by the same authors, the plantlets were transferred 60 days after germination into MS stationary liquid containing $10 \mu \mathrm{M}$ of BAP. After 60 days, only the 
plantlets that responded to the treatment were selected, using as reference the emission of adventitious shoots. These plantlets were replicated then expanded in the conditions described above and clones were obtained in order to continue the research.

Five plantlets of 11 clones selected to BAP were transferred to a greenhouse in the UCPB. Plantlets measuring 20 to $30 \mathrm{~mm}$ height possessing roots were acclimatized in plastic vases $100 \mathrm{~mm}$ in diameter $\mathrm{x} 80 \mathrm{~mm}$ in height with a $500 \mathrm{ml}$ capacity, filled with Bioplant ${ }^{\circledR}$, a commercial growth substrate. These vases were arranged in a completely randomized fashion, and five repetitions of 11 treatments (clones) were given; a vase containing one plant was considered to be an experimental unit. The plants were maintained in a greenhouse under shade screem sombrite ${ }^{\circledR} 70 \%$, receiving daily irrigation and fertilized weekly with $50 \mathrm{ml}$ of NPK (20-20-20) at a dose of $2 \mathrm{gl}^{-1}$.

After 190 days of acclimatization and development at the adult phase, before floral emission, a panel of five experts in bromeliads and ornamental plants evaluated the 11 clones. The experts evaluated five replica plants of each clone. For the selection of superior clones, the panel of experts assigned a subjective score ranging from zero to 10 in five important traits responsible for the commercial success of bromeliads. These included phytosanitary conditions, uniformity, plant color and shine, as well as espinescence expression. Together, these traits define the agronomic quality and ornamental potential of these plants. The sum of these scores produced an ornamental quality variable that was used to guide the selection of clones with high commercial production potential. Plant precocity was also considered for clone selection. Plants that emitted floral stem before 200 days of vase planting were considered to be precocious.

To the adjustment of the protocol for propagation in vitro, five clones were selected which presented the best means for produced score an ornamental variable quality. Then, the five clones selected were retrieved from stocks maintained in vitro at the Laboratory of Cell and Plant Tissue Culture. The experiment used shoots from these plantlets that were uniform in size and lacking roots. Five BAP levels $(0,10,2030$ and $40 \mu \mathrm{M})$ were tested on shoots arranged in a completely randomized design, with 3 replications, in stationary MS liquid medium, and a flask containing two plants was considered to be an experimental unit. The culture medium $\mathrm{pH}$ was adjusted to $5.7 \pm 0.01$ before sterilization at $121^{\circ} \mathrm{C}$ and $1.5 \mathrm{~atm}$ for 20 minutes. Flasks measuring 50x $140 \mathrm{~mm}$ with a $350 \mathrm{ml}$ volume were filled with $20 \mathrm{ml}$ of culture medium. The explants were incubated in a temperature-controlled room at $25 \pm 2^{\circ} \mathrm{C}$, with a 16-hour photoperiod and irradiance of $40 \mu \mathrm{mol}$ $\mathrm{m}^{-2} \mathrm{~s}^{-1}$ supplied by $40 \mathrm{~W}$ white fluorescent bulbs $\left(\right.$ Philips $^{\circledR}$ ).

This procedure was carried out individually for each clone selected. The effects of auxin were not tested at this stage as preliminary studies revealed that this class of growth regulator had no effect on the in vitro multiplication and growth of this species being in some bromeliads prejudicial to the growth (KIMBERLY et al., 2003). After 60 days of incubation, the traits evaluated were: mean length of the shoots and number of shoots per plantlet.

The results obtained by evaluating all of the parameters to score produced an ornamental quality variable were submitted to variance analysis and their means tested by the Scott-Knott test $(\mathrm{P}>0,01)$. The five clones presenting the best means at this stage were selected for further micro-propagation protocol adjustment.

The results obtained from the five clones micro-propagation were analyzed separately, submitted to variance analysis and their means were fitted to regression in order to adjust the protocol for each clone. Statistical analyses were performed using the computer program "GENES" (CRUZ, 2006). After multiplication and before acclimatization shoots shorter than $5.0 \mathrm{~mm}$ were elongated in MS liquid medium devoided of BAP.

\section{RESULTS AND DISCUSSION}

Seeds of $\boldsymbol{O}$. grossiorum germinated after 15 days of incubation in vitro, reaching a $100 \%$ germination rate. In stationary MS liquid medium supplemented with $10 \mu \mathrm{M}$ of BAP, only $18.33 \%$ (11 plantlets) responded to the treatment by emitting adventitious shoots, thus showing the great influence of the genotype on the response to growth regulators in vitro.

Shoot formation occurred through the development of adventitious buds that formed in the foliar axil region. Bromeliads in general are highly efficient at in vitro germination, with a rate above $90 \%$ being common for Vriesea hieroglyphica (MERCIER \& KERBAUY, 1995), Cryptanthus sinuosus (CARNEIRO et al., 1998), Tillandsia Eizii (KIMBERLY et al., 2003), Alcantarea imperialis (NAVES et al., 2003), Vriesea gigantea (DROSTE et al., 2005) and Neoregelia mucugensis (BELLINTANI et al., 2007).

The influence of the genotype on the success of propagation in vitro is well-known in the literature. For instance, LONE et al. (2008) similarly 
observed in orchids that only $18.7 \%$ of the genotypes selected from Dendrobium phalaenopsis responded to in vitro cultivation in MS medium.

Shoot formation occurred through the development of adventitious buds that were formed in the foliar axil region. The development of these adventitious buds made viable the mass multiplication of a large number of uniform plants.

The advantage of first selecting genotypes responsive to multiplication in vitro is to guarantee the availability of the selected clones in the market, since not all the genotypes selected in a standard breeding program can be multiplied in this fashion. This process minimizes the breeding program cost by reducing the size of breeding trials for the selection of ornamental plants. In this case, for instance, the $82 \%$ of the genotypes that were non-responsive to the in vitro stimuli applied were quickly eliminated.

This process is the inverse of the methods practiced by most ornamental plant breeders, as they usually first select plants of interest and only then try to introduce and multiply the genotypes in vitro sometimes unsuccessfully due to genotypic recalcitrance.

After 30 days of being planted in vases, the O. grossiorum clones were acclimatized to the ex vitro environment and started growing and there were emission of new leaves. All of the transferred clones presented distinct traits from one another, variations which intensified as they developed. These differences included color, length, width, and leaf thickness, the presence of scales on the leaf, thorn size, spacing between thorns, rosette diameter, and height of the plant's rosette, color of the inflorescence, presence of bunches, and floral tassel length (Table 1). The differences obtained are due to the rising of the pollination process. Plans were originate from a single fruit by open pollination. In open pollination has only the maternal parental control, not knowing paternal origin.

At 190 days after vase planting, at the imminence of floral emission and when leaf coloration is more intense in $\boldsymbol{O}$. grossiorum, an expert panel evaluated the plants for ornamental characteristics values. Five clones had an outstanding performance: 01, 04, 05, 08 and 09 (Table 2), displaying values above 50 out of 60 for the variable ornamental quality. The selection of clones with excellent agronomic and ornamental quality is important for the commercial success of the clone.

The clones selected were characterized by diversity in color and leaf size, scale presence, and size and spacing between thorns when compared to one another (Figure 1).

Selection of breeding processes can lead to narrowing of the genetic variability, and thus plants with ornamental value might not be selected. In this research, in vitro preselection was not detrimental to the point to discard all useful variability as the selected clones presented aggregating traits of ornamental interest (Figure 1).

Table 1 - Morphological description of the clones of the bromeliad Orthophytum grossiorum.

\begin{tabular}{|c|c|c|c|c|c|c|}
\hline Clone & Original & 01 & 04 & 05 & 08 & 09 \\
\hline $\begin{array}{l}\text { Leaf color of the abaxial } \\
\text { and adaxial face }\end{array}$ & Dark red & Reddish green & Greenish red & Rust red & Opaque rust red & Dark red \\
\hline $\begin{array}{l}\text { Presence of scales on the } \\
\text { adaxial face }\end{array}$ & Yes [1] & Yes [3] & Yes [1] & Yes [1] & Yes [1] & Yes [1] \\
\hline $\begin{array}{l}\text { Presence of scales on the } \\
\text { abaxial face }\end{array}$ & Yes [2] & Yes [5] & Yes [3] & Yes [3] & Yes [1] & Yes [4] \\
\hline Leaf length (mm) & $100-150$ & $110-130$ & $90-110$ & $120-160$ & $90-108$ & $85-100$ \\
\hline Leaf width (mm) & $19-22$ & $22-25$ & $20-25$ & $18-21$ & $16-19$ & $18-20$ \\
\hline Leaf thickness (mm) & $2-3$ & $3-4$ & $2-3$ & $2-3$ & 3 & $3-4$ \\
\hline Thorn size (mm) & 2 & $1.5-2$ & $1-2$ & $1.5-2$ & 2 & $1-1.5$ \\
\hline $\begin{array}{l}\text { Spacing between thorns } \\
(\mathrm{mm})\end{array}$ & 5 & $5-6$ & $4-6$ & $5-8$ & 5 & $3-4$ \\
\hline Rosette diameter(mm) & $190-230$ & $180-220$ & $160-200$ & $200-240$ & $200-210$ & $150-170$ \\
\hline Rosette height (mm) & $70-80$ & $70-80$ & $70-90$ & $70-80$ & $70-80$ & $60-80$ \\
\hline Number of leaves & 12 & 13 & 11 & 12 & 14 & 10 \\
\hline Color of inflorescence & Yellowish green & Yellowish green & Yellowish green & Yellowish green & Reddish green & Yellowish green \\
\hline $\begin{array}{l}\text { Presence of bunches on the } \\
\text { inflorescence }\end{array}$ & Yes & Yes & No & Yes & No & No \\
\hline Floral tassel length (mm) & 220 & 250 & 210 & 270 & 230 & 200 \\
\hline
\end{tabular}

Intensity:[1] very low, [2] low, [3] intermediary, [4] high, [5] very high 
Table 2 - Phytosanitary scores average (FtS), size uniformity (SU), color uniformity (CU), espinescence expression (EE), shine (S), ornamental potential (OP), and ornamental quality variable (OQV) of Orthophytum grossiorum.

\begin{tabular}{lccccccc}
\hline Clone & FtS & SU & CU & EE & S & OP & OQV \\
\hline 01 & $9,03^{\mathrm{a}}$ & $9,03^{\mathrm{a}}$ & $8,97^{\mathrm{a}}$ & $8,93^{\mathrm{b}}$ & $8,90^{\mathrm{b}}$ & $9,07^{\mathrm{a}}$ & $53,93^{*}$ \\
02 & $7,74^{\mathrm{e}}$ & $7,67^{\mathrm{f}}$ & $7,57^{\mathrm{f}}$ & $7,60^{\mathrm{g}}$ & $7,64^{\mathrm{e}}$ & $7,74^{\mathrm{e}}$ & 45,96 \\
03 & $7,48^{\mathrm{f}}$ & $7,38^{\mathrm{g}}$ & $7,52^{\mathrm{f}}$ & $7,41^{\mathrm{g}}$ & $7,48^{\mathrm{f}}$ & $7,41^{\mathrm{f}}$ & 44,68 \\
04 & $8,59^{\mathrm{b}}$ & $8,62^{\mathrm{b}}$ & $8,66^{\mathrm{b}}$ & $8,62^{\mathrm{c}}$ & $8,59^{\mathrm{c}}$ & $8,66^{\mathrm{b}}$ & $51,74^{*}$ \\
05 & $8,53^{\mathrm{b}}$ & $8,40^{\mathrm{c}}$ & $8,40^{\mathrm{c}}$ & $8,40^{\mathrm{d}}$ & $8,43^{\mathrm{c}}$ & $8,50^{\mathrm{c}}$ & $50,66^{*}$ \\
06 & $8,00^{\mathrm{d}}$ & $7,90^{\mathrm{e}}$ & $7,79^{\mathrm{e}}$ & $7,83^{\mathrm{f}}$ & $7,79^{\mathrm{e}}$ & $7,76^{\mathrm{e}}$ & 47,07 \\
07 & $8,26^{\mathrm{c}}$ & $8,15^{\mathrm{d}}$ & $8,19^{\mathrm{d}}$ & $8,15^{\mathrm{e}}$ & $8,19^{\mathrm{d}}$ & $8,12^{\mathrm{d}}$ & 49,06 \\
08 & $9,07^{\mathrm{a}}$ & $9,10^{\mathrm{a}}$ & $9,14^{\mathrm{a}}$ & $9,17^{\mathrm{a}}$ & $9,14^{\mathrm{a}}$ & $9,21^{\mathrm{a}}$ & $54,83^{*}$ \\
09 & $8,45^{\mathrm{b}}$ & $8,41^{\mathrm{c}}$ & $8,41^{\mathrm{c}}$ & $8,38^{\mathrm{d}}$ & $8,35^{\mathrm{d}}$ & $8,38^{\mathrm{c}}$ & $50,38^{*}$ \\
10 & $7,69^{\mathrm{e}}$ & $7,59^{\mathrm{f}}$ & $7,59^{\mathrm{f}}$ & $7,57^{\mathrm{g}}$ & $7,48^{\mathrm{f}}$ & $7,42^{\mathrm{f}}$ & 45,34 \\
11 & $7,11^{\mathrm{g}}$ & $6,97^{\mathrm{h}}$ & $6,97^{\mathrm{g}}$ & $7,07^{\mathrm{h}}$ & $7,07^{\mathrm{g}}$ & $7,10^{\mathrm{g}}$ & 42,29 \\
\hline
\end{tabular}

In each column, means followed by same letter do not differ by the Scott-Knott test $(\mathrm{P}>0.01)$

* selected clones

Size uniformity and the shape of thorns on the leaf margins, as well as the presence of scales associated with the rosette, enhance the beauty of the O. grossiorum plants and allow them to be characterized as ornamental even when they are not flowering. The presence of scales on the leaves allows bromeliads to adapt to environments extremely unfavorable to other plants and also confers the different shades of color to the leaves of $\boldsymbol{O}$. grossiorum.

Inflorescence is one of the characteristics of the plant that attracts most of attention and has a great impact on its commercial value. While the flower, by itself, is very small (5-mm on an average), the bract set surrounding the inflorescence highlights the contrast between the color of the rosette and the color of the flower, enhancing the commercial value of $\boldsymbol{O}$. grosssiorum plants. This contrast is observed mainly between the color of the inflorescence rosette and the color of the plant rosette in the clones selected for this research. The height and beauty of the floral tassel make this flower ideal for the production of floral arrangements (Figure 1), similar to the ornamental pineapple (BORGES et al., 2003).

However, in order to meet the needs of the consumer market, the plants selected must also be rustic and precocious, since distribution needs to be uniform and continuous without a drop in quality. The five clones selected in this research showed a superior performance in precocity and their resistance to damage caused by pests and diseases is reflection of rusticity.
The colorful, lush foliage and inflorescence of the bromeliads underlies their widespread use in landscaping and interior design (SOUZA et al., 2007). The plant under study in this research is special in the floriculture sector since it can be used as a vase flower, cut flower and garden flower (Figure 1). It is recommended as a vase flower for its aesthetic harmony and small size; as a cut flower for its height and beautiful floral tassel; and, as a garden flower in landscaping for the striking contrast of color between its rosette and inflorescence as well as its adaptability and rusticity.

In this study, it was determined that clones 01, 04, and 08 multiply better at lower BAP concentrations $(10 \mu \mathrm{M})$ than clones 05 and $09(20 \mu \mathrm{M})$. It was also observed that clones 05 and 08 were the most prolific, presenting, on average, 13.8 and 12.6 shoots per plantlet, respectively. The number of shoots observed in the other clones was fewer than six per plantlet, indicating that the response to BAP varies between the genotypes of $\boldsymbol{O}$. grossiorum.

The use of BAP in the culture medium to induce in vitro multiplication of $\boldsymbol{O}$. grossiorum reduced the length of the shoots produced, with the shortest lengths, in general, being observed at the highest BAP concentrations.

Despite the addition of this extra stage, shoot quality was not affected, as all of the shoots had roots and possessed no deformities or morphological alterations, and displayed a high acclimatization capacity.

The use of BAP in the culture medium to induce in vitro multiplication of $\boldsymbol{O}$. grossiorum reduced the length of the shoots produced, with the shortest lengths, in general, being observed at the highest BAP concentrations. This reduction in shoot length may be attributed to a decrease in the auxin/cytokinin ratio of the plantlets in vitro (TAIZ \& ZEIGER, 2008) and competition between emerging shoots, as the number of shoots increased in culture medium containing BAP. A similar phenomenon was observed by NAVES et al (2003), for A. imperialis, by MERCIER \& KERBAUY (1995) for Vriesea hieroglyphica and Vriesea forsteriana, and by PASQUAL et al. (2008) for Ananas comosus var. erectifolius. Reduction in shoot length led to addition of a subsequent shoot-elongation stage before the transfer of plantlets to the vases, conducted in the same culture medium but without BAP addition (PASQUAL et al., 2008). This new stage adds 30 days to the overall process.

Despite the addition of this extra stage, shoot quality was not affected, as all shoots had roots and possessed no deformities or morphological 


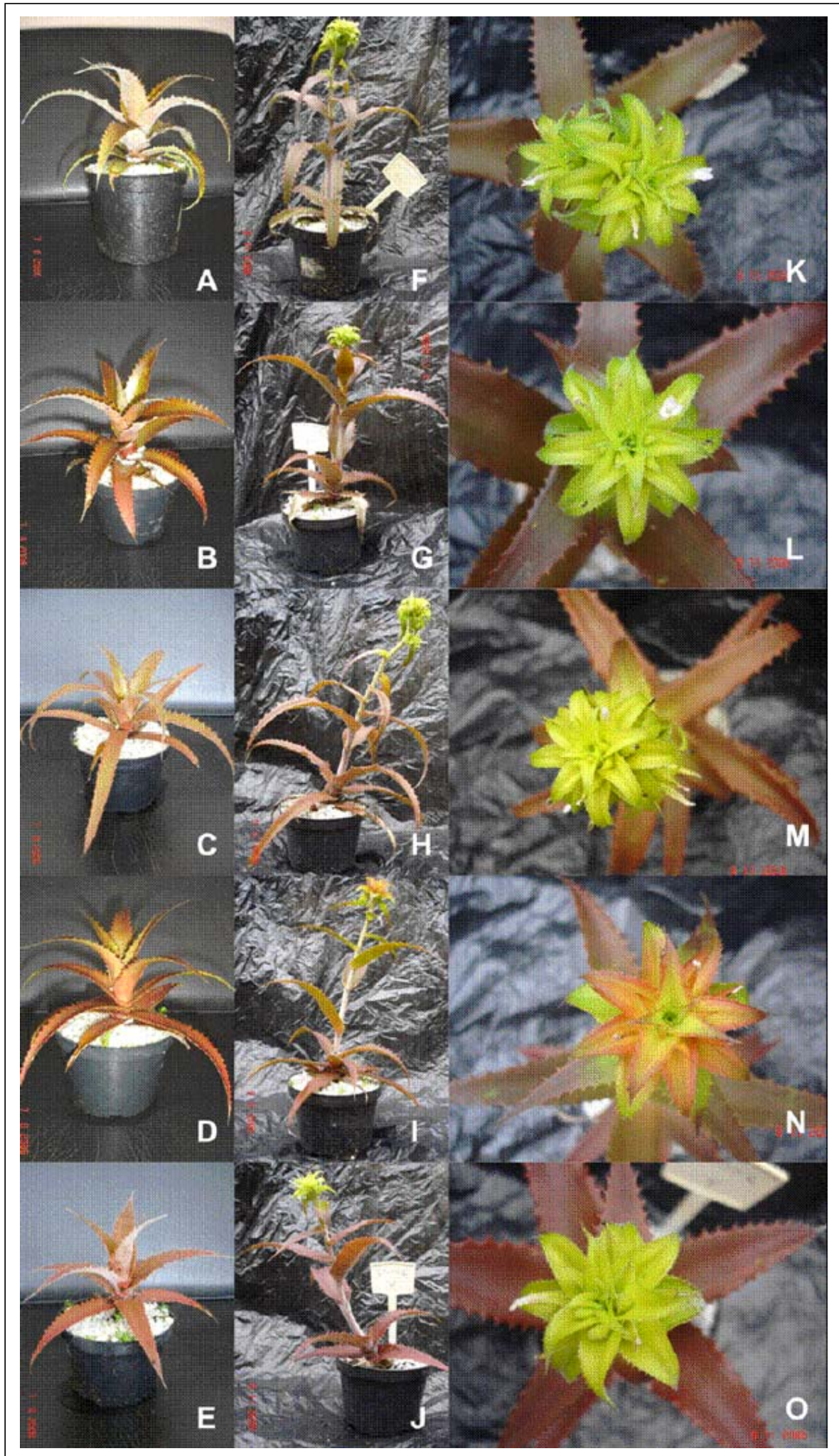

Figure 1 - Clones Selected of the bromeliad Orthophytum grossiorum. A-F-K) clone 01, B-G-L) clone 04; C-H-M) clone 05; D-I-N) clone 08; E-J-O) clone 09; A to E) plant at 200 days after transfer to the vase; $\mathrm{F}$ to $\mathrm{O}$ ) floral set of clone plants at 360 days after transfer to the vase. 
alterations, and displayed a high acclimatization capacity.

\section{CONCLUSION}

The process of pre-selection in vitro is interesting from the ornamental horticulture viewpoints, as it does not exclude plants with potential ornamental traits and reduces the cost of breeding ornamental bromeliads. The selection method proposed in this research was efficient for preselecting plants of ornamental value and ease of propagation, facilitating their domestication and commercial exploration when eventual multiplication in vitro is intended.

\section{ACKNOWLEDGMENTS}

Funding source: Fundação de Apoio à Pesquisa do Estado de Minas Gerais (FAPEMIG).

\section{REFERENCES}

ANDERSON, O.N. Flower breeding and genetics. USA:Springer, 2007. $801 \mathrm{p}$.

BELLINTANI, M.C. et al. Estabelecimento in vitro de Orthophytum mucugense e Neoregelia mucugensis, bromélias endêmicas da Chapada Diamantina, Bahia - Brasil. Revista Brasileira de Biociências, v.5, supl.2, p.11011103, 2007. Available from: <http://www6.ufrgs.br/seerbio/ ojs/index.php/rbb/article/view/872/719>. Accessed: Jul 19, 2009 .

BENZING, D.H. Bromeliaceae: profile of na adaptative radiation. USA: Cambridge, 2000. 675p.

BORGES, N.S.S. et al. Influência do meio bifásico na multiplicação de gemas e no alongamento de brotos in vitro de Ananas lucidus Miller. Revista Brasileira de Horticultura Ornamental, v.9, p.37-44, 2003. Available from: <http://www.sbfpo.com.br/revista/edicoes/09-1/ index.php >. Accessed: Jul 19, 2009.

CARNEIRO, L.A. et al. Clonal propagation of Cryptanthus sinuosus L.B. Smith, an endemic stoloniferous Bromeliaceae species from Rio de Janeiro, Brazil. Plant Tissue Culture And Biotechnology, v.4, p.152-158, 1998.

CRUZ, C.D. Programa GENES-versão Windows. Viçosa: UFV, 2006. 382p.

DROST, A. et al. In vitro Culture of Vriesea gigantea and Vriesea philippocoburgii: Two Vulnerable Bromeliads Native to Southern Brazil. Brazilian Archives of Biology and Tachnology, v.48, n.5, p.717-722, 2005. Available from: $<$ http://www.scielo.br/pdf/babt/v48n5/26606.pdf $>$. Accessed: Jul 21, 2009. doi: 10.1590/S1516-89132005000600006.

GUERRA, M.P. et al. Estabelecimento de um protocolo regenerativo para micropropagação do abacaxizeiro. Pesquisa Agropecuária Brasileira, v.34, p.1557-1563, 1999. Available from: <http://www.scielo.br/pdf/pab/v34n9/ 7606.pdf $>$. Accessed: Jul 20, 2009. doi: 10.1590/S0100204X1999000900005.
KIMBERLY, A.P. et al. Enhanced seed germination and seedling grwth of Tillandsia Eizii in vitro. HortScience, v.38, p.101-104, 2003. Available from: <http://cat.inist.fr/ ?aModele $=$ afficheN\&cpsidt $=14576331>$. Accessed: Jul 20, 2009. doi:13300/354000103958620220.

LEME, E.M.C.; PAULA, C.C. Uma nova espécie de Orthophytum de Minas Gerais, Brasil. Vidalia, v.1, n.1, p.15, 2003. Available from: http://www.vidalia.ufv.br/rlini.htm. Accessed: Jul 20, 2009.

LONE, A.B. et al. Seleção de genótipos de Dendrobium phalaenopsis (Orchidaceae) nas fases de propagação in vitro e aclimatização. Ciências Agrárias, v.29, n.4, p.755-760, 2008. Available from: <http://www.uel.br/revistas/uel/ index.php/semagrarias/article/view/2687/2334>. Accessed: Jul 20, 2009.

MINISTÉRIO DO MEIO AMBIENTE, 2009. Available from: $<$ http://www.mma.gov.br/estruturas/179/_arquivos/ 179 05122008033615.pdf>. Accessed: Ago 1, 2009.

MERCIER, H.; KERBAUY, G.B. The importance of tissue culture technique for conservation of endangered brazilian bromeliads from atlantic rain forest canopy. Selbyana,v.16, p.147-149, 1995. Available from: <http://www.scielo.br/ s cie loOrg/php/reflinks.php? refpid=S 1516 $8913200500060000600018 \&$ p id=S 1516 $89132005000600006 \& \operatorname{lng}=\mathrm{en}>$. Accessed: Jul 21, 2009

MERCIER, H; NIEVOLA, CC. Obtenção de bromélias in vitro como estrategia de preservação. Vidalia, v.1, n.1, p.5762, 2003. Avalaible from: http://www.scielo.br/scieloOrg/php/ $\mathrm{r}$ e f $1 \mathrm{i}$ n k s. p h p ? r e f p i d = S 1677 0420200700020000400014 \& p id=S 1677 04202007000200004\&lng=en. Accessed: Jul 21, 2009.

MURASHIGE, T.; SKOOG, F. A revised medium for rapid growth and bioassays with tobacco tissue culture. Physiologia Plantarum, v.15, p.473-497, 1962.

NAVES, V.C. et al. Avaliação de diferentes concentrações dos meios de cultura MS e Knudson para propagação in vitro de bromélia imperial (Alcantarea imperialis (Carrière) Harms. Revista Brasileira de Horticultura Ornamental, v.10, p.120-124, 2003. Available from: < http://www.sbfpo.com.br/ rbho/index.php/rbho/issue/view/59 >. Accessed: Jul 20, 2009.

PAEK, K.Y.; HAHN, E.J. Cytokinins, auxins and activated charcoal affect organogenesis and anatomical characteristics of shoo-tip cultures of Lisianthus [(Eustoma grandiflorum (Raf.) Shinn]. In vitro Cellular and Developmental Biology-Plant, v.36, p.128-132, 2000. Avalaible from: $<$ http://www.springerlink.com/content/c74jr74j32815678 >. Accessed: Jul 20, 2009. doi: 10.1007/s11627-000-0026-2.

PASQUAL, M. et al. Micropropagação do abacaxizeiro ornamental. Horticultura Brasileira, v.26, n.1, p.45-49, 2008. Available from: <http://www.scielo.br/pdf/hb/v26n1/ a09v26n1.pdf $>$. Accessed: Jul 21, 2009. doi: 10.1590/S010205362008000100009 .

POMPELLI, M.F.; GUERRA, M.P. Enraizamento in vitro e ex vitro de Dyckia distachya Hassler, sob diferentes concentrações de AIB. Floresta e Ambiente, v.12, p.42-49, 2006 . 
RECH FILHO, A. et al. Tissue culture for the conservation and mass propagation of Vriesea reitzii Leme and Costa, a bromeliad threatened of extinction from the Brazilian Atlantic Forest. Biodiversity and Conservation, v.14, n.8, p.17991808, 2005. Avalaible from: <http://www.scielo.br/pdf/cr/ v39n3/a88cr537.pdf>. Accessed: Jul 22, 2009. doi: 10.1590/ S0103-84782008005000088.

SILVA, A.B. et al. Métodos de micropropagação do abacaxizeiro. Pesquisa Agropecuária Brasileira, v.42, n.9, p.1257-1260, 2007. Available from: <http://www.scielo.br/ pdf/pab/v42n9/06.pdf>. Accessed: Jul 21, 2009. doi: 10.1590/ S0100-204X2007000900006.

SOUZA, F.V.D. et al. Caracterizaçao morfológica de abacaxizeiros ornamentais. Magistra, v.19, p.319-325, 2007. Available from: <http://www.magistra.ufrb.edu.br/ publica/19.4\%20PDF/Artigos\%20Magistra\%202007\%20\%209.pdf>. Accessed: Jul 22, 2009.

TAIZ, L.; ZEIGER, E. Fisiologia vegetal. 4.ed. Porto Alegre: ARTMED, 2008. 820p. 